\title{
USE OF MOSSES FOR THE SURVEY OF HEAVY METAL DEPOSITION IN AMBIENT AIR OF THE KATHMANDU VALLEY APPLYING ACTIVE MONITORING TECHNIQUE
}

\author{
Kumudini Shakya, Mukesh K. Chettri and Thomas Sawidis* \\ Department of Botany \\ Amrit Science Campus, Tribhuvan University, Kathmandu, Nepal \\ Email: kumushakya@yahoo.com \\ *Department of Botany \\ Aristotle University of Thessaloniki, Thessaloniki, Greece
}

\begin{abstract}
To understand the level of heavy metals $(\mathrm{Cd}, \mathrm{Co}, \mathrm{Cr}, \mathrm{Cu}, \mathrm{Pb}, \mathrm{Mn}, \mathrm{Ni}$ and $\mathrm{Zn})$ in the ambient air of the Kathmandu valley, active monitoring technique using mosses was performed. Common mosses like Taxiphyllum giraldii (C. Muell.) Fleisch., Thuidium sparsifolium (Mitt.) Jaeg., and the leafy liverwort Ptychanthus striatus (Lehm. \& Linderb.) Nees. collected from Phulchowki (a clean natural area) were transplanted at 25 different sites of the valley and were exposed for 3 months. These sites were broadly divided into 3 categories on the basis of vehicular traffic: inside Ring Road (high traffic), along Ring Road (high to moderate traffic) and outside the Ring Road (moderate to lax traffic). Three sites - Shivapuri (North-east), Raniban (North-west) and Phulchowki (South-east) were considered as control sites. Contamination Factor (CF) value obtained from the heavy metal concentration in exposed mosses indicated high contaminated sites mostly along and inside the ring road (except $\mathrm{Zn}$ which was found to be higher outside the ring road). On the basis of the average concentrations of the elements in the transplanted mosses, a general picture of air quality of the studied area has been ascertained. From this study, it can be made certain that ambient air of the Kathmandu valley is severely contaminated with $\mathrm{Pb}, \mathrm{Cr}$ and $\mathrm{Zn}$ and relatively low with $\mathrm{Co}, \mathrm{Cu}, \mathrm{Mn}$ and $\mathrm{Ni}$.
\end{abstract}

Key words: Active monitoring, mosses, heavy metals, Kathmandu valley.

\section{INTRODUCTION}

The idea of using mosses to measure atmospheric heavy metal deposition was developed in the late 1960s in Sweden (Ruhling and Tyler 1968, Tyler 1970). Biomonitoring using moss is a well developed technique now employed in many parts of the world to assess the concentration of trace element in the ambient air (Sawidis et al. 1993, Steinnes 1995, Loppi and Bonini 2000,
Fernandez et al. 2000, Shakya et al. 2004, Saxena et al. 2008, Saxena and Arfeen 2010). These leafy bryophytes are perennial without deciduous periods and obtain most of their nutrients and pollutants directly from precipitation and dry deposition of atmospheric particles. Also, they have high cation exchange capacity that allows them to accumulate large amount of heavy metals between the apoblast and symplast of 
compartments without damaging vital functions of the cells (Vasquez et al. 1999). Thus, they can capture, retain, and tolerate metals to a high degree.

Responses of plants, either living in or transplanted to the area studied can be used to obtain information on quality of the environment. Mosses have often been used in passive biomonitoring, i.e. where native species are used in the area under study (Steinnes et al. 1992, Fernandez et al. 1997, Shakya et al. 2004). When there is an absence of native mosses, transplants can often be used and the biomonitoring of this kind is called active biomonitoring (Viskeri et al. 1997). Thus, transplantation is an experimental technique where study plants are transferred, along with their original substratum, from unpolluted control areas to suspected or known polluted areas. This technique is very useful especially in such polluted areas where wild growing mosses are lacking (Makholm and Miadenoff 2005). The effects and responses of the transplants are subsequently examined after a measured time scale and compared to the control areas. In terms of aerial metal monitoring using transplants, levels in tissues rather than effects are measured before and after the exposure period (Fernandez et al. 2000, Saxena et al. 2008). The main property of the transplantation technique is the possibility to detect toxic effects of environmental pollutants on the biomonitor, and use this information as a signal to the impact of the contaminant (Figuera and Ribeiro 2005). Even dead moss tissues preserve their adsorption capacity (Sucharova and Suchara 2000) which is evident from the work of Goodman and Roberts (1971). They transplanted logs with attached Hypnum cupressforme into industrial areas in Wales, the transplants died after some weeks but it continued to accumulate metals even after death.

The transplantation technique, apart from being considerably cheaper, is readily applicable every time of the year (with carefully selected plant species) and everywhere without much preliminary preparation (Tuba and Csintalan 1993). The appropriate length of exposure for the accumulation of most metals was determined by several criteria such as detectable accumulated concentrations, reliable values, and as exposure time with the limits of practical consideration (Gailey and Lloyd 1986). So, even short term exposures give reliable indication of heavy metal pollution.

Rapid urbanization in the Kathmandu valley has resulted in a significant deterioration in air quality. Vehicular emissions, poor infrastructure, re-suspension of street dust and litter, black smoke plumes from brick kilns, fuel burning and stone grinding factories are among the many sources contributing to increased air pollution in the Kathmandu valley (Shrestha 2000). The number of vehicle registered in Bagmati Zone is ever increasing. While the number registered in this Zone in 2000/01 was less than 27 thousand, it had reached close to 50 thousand by $2009 / 10$, with the total number now at 250 thousand, which amounts to $56 \%$ of all vehicles registered in the country during the 2006-2010 period (DoTM 2010).

The regular monitoring of the level of the hazardous metallic pollutants is necessary to determine their impact upon the ecosystem. To know the heavy metal contamination in ambient air of the Kathmandu valley, both passive and active monitoring using lichens have been conducted (Chettri et al. 2001) and only passive monitoring has been conducted using native mosses (Shakya $e t$ al. 2004), but active monitoring by moss transplantation technique has not been carried out so far. Hence, mosses (Taxiphyllum giraldii and Thuidium sparsifolium) and a leafy liverwort (Ptychanthus striatus) with high bioaccumulation in the uptake experiment under laboratory condition have been evaluated in the present study to ascertain the level of heavy metal pollution in the ambient air of the Kathmandu valley.

ECOPRINT VOL 19, 2012 


\section{MATERIALS AND METHODS}

\section{Sites, transplantation and sample preparation}

Two epiphytic mosses Taxiphyllum giraldii and Thuidium sparsifolium and a leafy liverwort Ptychanthus striatus, found in clean natural areas like Phulchowki $10 \mathrm{~km}$ SW from main Kathmandu city were collected along with branches. Branches of about $30-50 \mathrm{~cm}$ of length with healthy cover of these mosses and leafy liverwort were chosen. The branches from the clean area (Phulchowki) were transplanted to 25 different exposure sites (Fig. 1), which are categorized into three different types based on traffic flow 1) Inside the Ring Road (high traffic flow), 2) along the Ring Road (high to moderate traffic flow) and 3) outside the RingRoad (moderate to lax traffic flow).

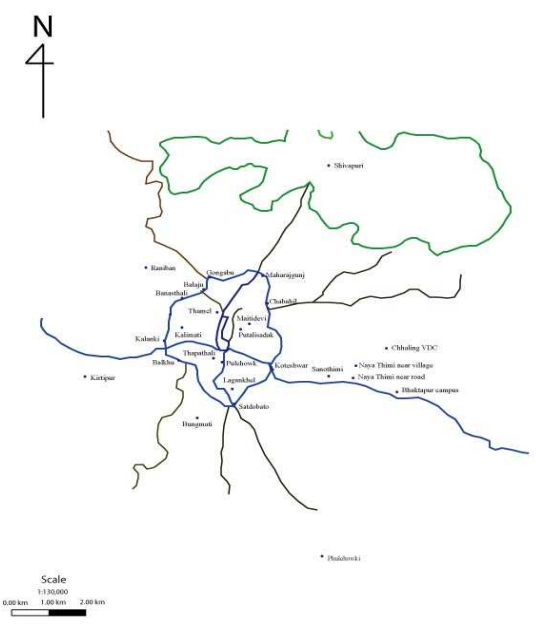

Fig. 1. Transplanted sites for active monitoring using moss transplants in the Kathmandu valley.

At each sites, five twigs were suspended horizontally at the height of 1.5-2 m either on trees or on house fences (where trees were unavailable) by the use of synthetic plastic cords. These mosses and leafy liverwort were also suspended to different clean areas of the valley like Shivapuri (North-east) and Raniban (North-west) and also resuspended at Phulchowki (South-east), for control.

The mosses were transplanted in the mid of September and suspended up to mid December, 2006 for three months. At the end of the exposure period, the mosses with the twigs were collected in plastic bag, transported to laboratory, cleaned and representative sample of each species from each site was prepared.

\section{Metal analysis}

Metal analysis in mosses was done according to Sawidis et al. (1993). 1 g oven-dry treated samples were digested with $10 \mathrm{ml}$ concentrated $\mathrm{HNO}_{3}$ (analyzer grade - Merck) by warming for 2 hours at $50{ }^{\circ} \mathrm{C}$ and subsequent heating to $160^{\circ} \mathrm{C}$ for 4 hours. The extract was filtered through ash less filter paper (Whatman type 589/2 - blue ribbon) and the filtrate was diluted to $25 \mathrm{ml}$ with deionised water.

The metal contents $\mathrm{Cd}, \mathrm{Co}, \mathrm{Cr}, \mathrm{Cu}, \mathrm{Mn}, \mathrm{Ni}, \mathrm{Pb}$ and $\mathrm{Zn}$ in the filtrate were determined by Atomic Absorption Spectrophotometry (Perkin Elmer 2380) using an air- acetylene flame. The analytical wavelengths used were 228.8, 240.7, 357.9, 324.7, 279.5, 232.0, 283.3 and $213.9 \mathrm{~nm}$ for $\mathrm{Cd}, \mathrm{Co}, \mathrm{Cr}$, $\mathrm{Cu}, \mathrm{Mn}, \mathrm{Ni}, \mathrm{Pb}$ and $\mathrm{Zn}$, respectively (Welz 1985).

\section{Contamination Factor (CF) using transplants}

To know the different metal contamination in the different transplanted sites of Kathamandu valley, the metal concentration in control moss specimens from foot hill of Phulchowki, Shiva puri and Raniban were considered as the background level. In the case of active monitoring, mean of the metal concentration recorded in suspended or resuspended moss and leafy liverworts at control stations (located at non-contaminated sites of the survey area) has been considered as background level. 
The degree of contamination of each metal at each sampling site was classified following the calculation of contamination factor (CF) according to Fernandez and Carballeira (2001).

$\mathrm{CF}=\mathrm{Cm} / \mathrm{Cb}$, where $\mathrm{Cm}$ is the concentration of an element measured in transplanted moss species and $\mathrm{Cb}$ is the background level of the element in the moss.

The contamination factor was categorized as follows:

$$
\begin{aligned}
& \mathrm{C} 1=(\mathrm{CF} 0-1) \text { No contamination } \\
& \mathrm{C} 2=(\mathrm{CF}>1-2) \text { Suspected contamination } \\
& \mathrm{C} 3=(\mathrm{CF}>2-3.5) \text { Slight contamination } \\
& \mathrm{C} 4=(\mathrm{CF}>3.5-8) \text { Moderate contamination } \\
& \mathrm{C} 5=(\mathrm{CF}>8-27) \text { Severe contamination } \\
& \mathrm{C} 6=(\mathrm{CF}>27) \text { Extreme contamination }
\end{aligned}
$$

\section{Statistical analysis}

Results of means of chemical analysis for transplanted and resuspended mosses were evaluated with one way analysis of variance (ANOVA) followed by Duncan's multiple range tests to compare metal concentrations in each of the plants exposed in four different sites- inside Ring Road, along Ring Road, outside Ring Road and control sites,

\section{RESULTS AND DISCUSSION}

Bioccumulation of heavy metals by
transplanted mosses

The concentration of metals $(\mathrm{Cd}, \mathrm{Co}, \mathrm{Cr}, \mathrm{Cu}$, $\mathrm{Mn}, \mathrm{Ni}, \mathrm{Pb}$ and $\mathrm{Zn}$ ) in transplanted mosses and leafy liverwort is given in Table 1. Mean concentrations of different metals inside the Ring Road, along the Ring Road and outside the Ring Road measured in transplanted mosses and leafy liverwort is given in Table 2. Details about accumulation of each airborne metal are described below.

Cadmium: Accumulation of $\mathrm{Cd}$ in transplanted mosses and leafy liverworts were not in detectable amount in most sites (Table 1). Mean concentrations of $\mathrm{Cd}$ in transplanted $T$. sparsifolium and $T$. giraldii were detected relatively high along Ring Road (Table 2) as its concentrations in transplanted mosses at Chabahil and Gongabu has been recorded high, which must be due to more vehicular movement in those areas.

Cobalt: Mean concentrations of Co in transplanted $T$. giraldii, $T$. sparsifolium and $P$. striatus were insignificantly high inside the Ring Road. Similarly, insignificant high Co accumulation was observed in $T$. giraldii and $T$. sparsifolium transplanted out side the Ring Road (Table 2). Contamination of Co (> $7 \mathrm{mg} / \mathrm{kg}$ ) was noticed in Kalimati, Lagankhel, Thamel, Maitidevi, and Putalisadak inside Ring Road; Balaju, Balkhu, Kalanki and Satdobato along the Ring Road; Bhaktapur Itapako, Chhaling VDC, Naya Thimi (near village), Kirtipur and Bugmati outside the Ring Road (Table 1). Emission from different anthropogenic activities like burning of coal, industries that make or use cutting or grinding tools, turbines, metal industrial discharge, production of cobalt alloys, dye etc. might be the reason for its accumulation.

Chromium: Mean concentration of $\mathrm{Cr}$ in transplanted $T$. girarldii and $T$. sparsifolium was higher than $P$. striatus. Accumulation of $\mathrm{Cr}$ was significantly $(\mathrm{P}=0.05)$ high in $T$. giralldii inside Ring Road and in T. sparsifolium along the Ring Road (Table 2). Slightly high accumulation of $\mathrm{Cr}$ (>10 mg/kg) in $T$. girarldii and $T$. sparsifolium was noticed in Lagankhel, Pulchowk, Putalisadak, Thamel and Thapathali inside the Ring Road; Balaju, Chabhil, Gangabu, Kalanki, Koteshwor and Satdobato along Ring Road (Table 1) showed relatively substantial amounts of $\mathrm{Cr}$ concentrations in the proximity of high vehicular flow. The automobile industry is a major user of $\mathrm{Cr}$, primarily as additive in unleaded gasoline, in recirculation cooling waters (antifreezers), as paints on automobile bodies, as trims and alloys on 
automotive parts and in car metal plating (Ward 1988). Hence, the dispersion of $\mathrm{Cr}$ from the vehicular activity to the adjacent environment is suspected.

Copper: Mean concentration of $\mathrm{Cu}$ in transplanted $T$. girarldii and $T$. sparsifolium were significantly high $(\mathrm{P}=0.05)$ inside and along the Ring Road. Insignificant differences in $\mathrm{Cu}$ accumulation were observed inside, along and outside the Ring Road in transplanted $P$. striatus (Table 2). High accumulation $(>25 \mathrm{mg} / \mathrm{kg}$ ) of $\mathrm{Cu}$ in $T$. girarldii and/or T. sparsifolium was noticed in Lagankhel, Thamel and Thapathali inside Ring Road; Balaju, Kalanki, Satdobato and Banasthali along Ring Road; and Bungmati outside Ring Road (Table 1). Copper contents of transplanted mosses and leafy liverwort were mostly higher than that of the control. High $\mathrm{Cu}$ along Ring Road may be due to high vehicular traffic. But transplants in Bungmati area, which is remote with very low traffic emission, also showed high $\mathrm{Cu}$ accumulation and has been speculated due to emissions from the cottage industries mostly involved in smelter works like melting metals: copper, brass, iron etc and preparing small antique items for tourists.

Manganese: Concentrations of $\mathrm{Mn}$ in transplanted T. sparsifolium were highest in most places among three tested species. Mean concentrations of Mn was significantly high $(\mathrm{P}=0.05)$ along Ring Road in T. sparsifolium and T. giraldii (Table 2). An insignificant difference in Mn accumulation was observed inside, along and outside the Ring Road in transplanted $P$. striatus. High accumulation of Mn (>90mg/kg) was noticed in most transplanted mosses and leafy liverwort (Table 1), including control areas. Manganese accumulation in transplanted mosses and leafy liverworts were mostly lower than that in control areas. Almost identical values were recorded in most of the transplanted sites. $\mathrm{Mn}$ is a major mineral in higher plants, and may be easily supplied to the transplanted moss by foliar leaching. In fact, foliar leaching may be important for the Mn content of moss (Schaug et al. 1990). The contents of Mn is not a good indicator of pollution, as large amounts of this metal enter exchange reactions with other elements occurring in large quantities (Steinnes 1989).

Nickel: Accumulation of $\mathrm{Ni}$ in $T$. giraldii is significantly $(\mathrm{P}>0.05)$ high inside and along the Ring Road, but in other two species it is insignificantly different (Table 2). High accumulation of $\mathrm{Ni}(>10 \mathrm{mg} / \mathrm{kg})$ in $T$. giraldii and/or T. sparsifolium was observed in Lagankhel, Pulchowk, Thapathali inside the Ring Road, which has been speculated due to high vehicular traffic emissions, refuse incineration of municipal waste and welding iron works (Ward 1989). Ni can be found in brake, clutch discs and tyres.

Lead: Accumulation of airborne $\mathrm{Pb}$ in transplanted $T$. giraldii and $T$. sparsifolium was found to be higher than in $P$. striatus. $\mathrm{Pb}$ concentrations in transplanted mosses were significantly $(\mathrm{P}=0.05)$ high inside and along the Ring Road (Table 2). High accumulation of $\mathrm{Pb}(>50 \mathrm{mg} / \mathrm{kg})$ have been recorded in mosses $T$. giraldii and $T$. sparsifolium transplanted at Kalimati, Lagankhel, Maitidevi, Pulchowk, Putalisadak, Thamel, Thapathali inside the Ring Road; Balaju, Chabahil, Gongabu, Kalanki, Maharajgunj, Satdobato, Banasthali along the Ring Road; Sanothimi, Bhaktapur Itapako, Chhaling VDC, Naya Thimi (Near road) outside the Ring Road (Table 1). Lead seemed to be main important polluting element in most of the transplanted sites. Its concentrations in the transplanted mosses and leafy liverwort were mostly higher than that in the control areas. Along and inside the Ring Road showed significantly high contents of $\mathrm{Pb}$, which have been speculated due to high vehicular movement. The main source of $\mathrm{Pb}$ contamination is motor vehicle traffic. The traffic density of the individual sites of the study areas is 
considerably higher than that of the control sites. The further local pollution source of $\mathrm{Pb}$ is the use of adulterated fuel. The use of the leaded petrol, though band in 1995 is also affecting the air quality of the valley. A spectacularly increased number of vehicles in the narrow and congested road move at the rate of $3-4 \mathrm{~km} / \mathrm{h}$ and very often is causing traffic jam. Possibly traffic jam at most of these areas may be the reason for high accumulation of $\mathrm{Pb}$.

Zinc: High accumulation of $\mathrm{Zn}$ was observed in transplanted $T$. giraldii and $T$. sparsifolium along the Ring Road and outside the Ring Road but in $P$. striatus $\mathrm{Zn}$ accumulation was highest inside the Ring Road. High Zn accumulation (>150 mg/kg) was observed at Thapathali inside Ring Road; Balkhu, Gangabu, Kalanki, Satdobato and Banasthali along the Ring Road; Bhatktapur campus, Sanothimi Brick kiln and Bhaktapur Itapako outside the Ring Road (Table 1). Local source like emissions from a large number of brick kilns around these areas is primarily responsible for the elevated level of contamination. Usually, low grade coal and coal dusts are used in brick kilns (ENPHO 2001). During coal combustion, heavy metals enter the environment either as fine metallic aerosols in the stack gases or as fly ashes (Clarke and Sloss 1992, Palmieri et al. 1997). Thus, the volatile trace elements like As, Be, Cd, $\mathrm{Fl}$ and $\mathrm{Zn}$ are discharged directly into the atmosphere (Wilson et al. 1986). Sometimes people even use waste tyre of vehicles, the combustion of which emits ultra-fine particles that include different heavy metals like $\mathrm{As}, \mathrm{Cd}, \mathrm{Cr}, \mathrm{Hg}$, $\mathrm{Pb}$ and $\mathrm{Zn}$. Zinc contamination in some other areas likes Thapathali inside the Ring Road; Balkhu, Gongabu, Kalanki, Satdobato and Banasthali along the Ring Road might be due to increasing traffic densities (Ward 1989). Particles emitted by automobile tyers are the major sources of $\mathrm{Zn}$ particles (Christersen and Guim 1979, Councell et al. 2004). Not only tyres but also lubricating oils and brake pads and galvanized automobile parts are also sources of $\mathrm{Zn}$ (Fytianos et al. 1985), which might have caused in the high content of this metal in those areas.

Table 1. Concentrations of heavy metals $(\mathrm{mg} / \mathrm{kg})$ in mosses and leafy liverwort transplanted at different places (inside, along and outside Ring Road) of Kathmandu valley and also transplanted in clean areas (Raniban, Phulchowki and Shivapuri National Park) for control.

\begin{tabular}{llllllllll}
\hline Transplanted sites & Moss sp. & Cd & Co & Cr & Cu & Mn & Ni & Pb & Zn \\
\hline Inside Ring Road & & & & & & & & & \\
Kalimati & T. giraldii & 0.50 & 7.25 & 3.25 & 9.50 & 66.50 & 2.00 & 54.30 & 29.25 \\
& T. sparsifolium & 0.25 & 7.75 & 5.00 & 12.50 & 89.50 & 1.50 & 42.65 & 44.00 \\
& P. striatus & 0.25 & 11.00 & 3.00 & 17.00 & 77.25 & 3.25 & 26.50 & 65.50 \\
Lagankhel & T. giraldii & 1.25 & 6.00 & 6.25 & 36.75 & 101.75 & 10.00 & 74.90 & 102.50 \\
& T. sparsifolium & 2.00 & 7.75 & 11.25 & 33.50 & 123.25 & 12.50 & 82.50 & 90.00 \\
Maitidevi & P. striatus & 0.23 & 5.25 & 8.25 & 42.00 & 99.75 & 8.75 & 37.50 & 100.00 \\
& T. giraldii & 0.23 & 11.00 & 4.00 & 19.00 & 90.50 & 5.00 & 74.90 & 50.75 \\
& T. sparsifolium & 0.23 & 7.75 & 5.00 & 17.50 & 83.50 & 3.75 & 62.40 & 64.75 \\
Pulchowk & P. striatus & 0.23 & 9.00 & 5.00 & 17.00 & 94.75 & ND & 24.20 & 60.00 \\
& T. giraldii & 0.54 & 2.50 & 10.25 & 20.00 & 50.00 & 10.00 & 70.20 & 75.00 \\
& T. sparsifolium & 1.25 & 6.50 & 10.00 & 17.75 & 88.00 & 5.00 & 62.50 & 87.50 \\
& P. striatus & 0.23 & 1.25 & 7.50 & 15.00 & 52.50 & ND & 25.40 & 105.00
\end{tabular}




\begin{tabular}{|c|c|c|c|c|c|c|c|c|c|}
\hline \multirow[t]{3}{*}{ Putalisadak } & T. giraldii & $\mathrm{ND}$ & 7.50 & 20.00 & 21.25 & 61.25 & 7.50 & 75.20 & 84.00 \\
\hline & T. sparsifolium & 2.50 & 7.50 & 15.00 & 20.00 & 88.50 & 5.00 & 80.50 & 115.00 \\
\hline & P. striatus & 2.00 & 8.00 & 7.50 & 16.00 & 96.50 & 2.50 & 25.40 & 75.00 \\
\hline \multirow[t]{3}{*}{ Thamel (Campus) } & T. giraldii & 2.50 & 7.50 & 21.25 & 25.75 & 125.00 & 6.75 & 75.20 & 122.50 \\
\hline & T. sparsifolium & 1.75 & 6.25 & 10.00 & 13.75 & 109.50 & 5.00 & 62.50 & 87.50 \\
\hline & P. striatus & $\mathrm{ND}$ & 10.75 & 12.50 & 23.50 & 100.00 & 2.50 & 14.75 & 62.50 \\
\hline \multirow[t]{3}{*}{ Thapathali } & T. giraldii & 2.50 & 5.00 & 25.00 & 25.00 & 79.00 & 10.00 & 73.60 & 78.00 \\
\hline & T. sparsifolium & 3.75 & 1.25 & 37.50 & 20.00 & 127.00 & 12.50 & 87.50 & 250.00 \\
\hline & P. striatus & ND & 0.75 & 5.75 & 15.00 & 113.25 & 10.00 & 74.80 & 175.00 \\
\hline \multicolumn{10}{|l|}{ Along Ring Road } \\
\hline \multirow[t]{3}{*}{ Balaju } & T. giraldii & ND & 6.50 & 12.50 & 12.50 & 87.75 & ND & 65.00 & 49.75 \\
\hline & T. sparsifolium & ND & 7.50 & 12.50 & 31.25 & 125.00 & 5.00 & 50.00 & 131.00 \\
\hline & P. striatus & ND & 1.25 & 10.00 & 27.25 & ND & 8.50 & 37.50 & 53.75 \\
\hline \multirow[t]{3}{*}{ Balkhu } & T. giraldii & ND & 3.75 & 7.50 & 14.75 & 237.50 & 7.50 & 30.00 & 175.00 \\
\hline & T. sparsifolium & ND & 7.25 & 3.25 & 22.50 & 93.75 & 8.75 & 37.50 & 125.00 \\
\hline & P. striatus & ND & 8.50 & 5.25 & 16.25 & 113.75 & 4.75 & 10.00 & 77.00 \\
\hline \multirow[t]{3}{*}{ Chabahil } & T. giraldii & 2.50 & 1.75 & 11.25 & 15.00 & 250.00 & 8.75 & 84.00 & 125.00 \\
\hline & T. sparsifolium & 2.50 & 1.50 & 19.50 & 15.50 & 175.00 & 5.50 & 75.00 & 187.50 \\
\hline & P. striatus & 0.50 & 1.50 & 5.25 & 11.00 & 80.25 & 3.00 & 17.00 & 29.00 \\
\hline \multirow[t]{3}{*}{ Gongabu Bus park } & T. giraldii & 1.75 & 2.25 & 25.00 & 20.00 & 125.00 & 6.25 & 75.00 & 250.00 \\
\hline & T. sparsifolium & 2.25 & 2.00 & 37.50 & 18.75 & 100.00 & 9.50 & 62.50 & 100.00 \\
\hline & P. striatus & 1.63 & 2.25 & 4.50 & 11.75 & 89.50 & 4.25 & 21.00 & 46.75 \\
\hline \multirow[t]{3}{*}{ Kalanki } & T. giraldii & $\mathrm{ND}$ & 6.00 & 20.50 & 24.75 & 105.25 & 7.50 & 75.00 & 170.00 \\
\hline & T. sparsifolium & ND & 7.50 & 22.50 & 30.00 & 212.50 & 8.75 & 86.75 & 137.50 \\
\hline & P. striatus & ND & 5.00 & 8.25 & 21.00 & 125.00 & ND & 7.25 & 62.50 \\
\hline \multirow[t]{3}{*}{ Koteshwor } & T. giraldii & ND & 2.50 & 6.50 & 19.00 & 158.75 & 7.75 & 45.00 & 75.00 \\
\hline & T. sparsifolium & ND & 5.25 & 15.00 & 20.00 & 175.00 & 6.00 & 32.50 & 87.50 \\
\hline & P. striatus & ND & 3.75 & 10.00 & 16.00 & 90.50 & 6.50 & 27.50 & 50.00 \\
\hline \multirow[t]{3}{*}{ Maharajgunj } & T. giraldii & ND & 3.25 & 5.50 & 14.25 & 96.75 & 6.50 & 62.50 & 67.00 \\
\hline & T. sparsifolium & $\mathrm{ND}$ & 5.25 & 9.75 & 16.75 & 150.00 & 9.25 & 75.00 & 70.00 \\
\hline & P. striatus & ND & 1.50 & 7.00 & 13.50 & 86.75 & 6.25 & 35.00 & 57.50 \\
\hline \multirow[t]{3}{*}{ Satdobato } & T. giraldii & $\mathrm{ND}$ & 5.75 & 2.50 & 37.50 & 97.00 & 7.25 & 78.00 & 175.00 \\
\hline & T. sparsifolium & ND & 8.00 & 12.50 & 21.75 & 106.75 & 8.00 & 67.00 & 162.50 \\
\hline & P. striatus & $\mathrm{ND}$ & 5.25 & 17.50 & 23.75 & 95.00 & 7.50 & 34.00 & 70.00 \\
\hline \multirow[t]{3}{*}{ Banasthali } & T. giraldii & ND & 2.50 & 8.75 & 32.25 & 105.75 & 3.75 & 57.50 & 65.00 \\
\hline & T. sparsifolium & $\mathrm{ND}$ & 3.75 & 7.25 & 31.00 & 400.00 & 5.75 & 65.00 & 175.00 \\
\hline & P. striatus & 0.5 & 2.25 & 6.50 & 25.75 & 97.75 & 6.00 & 52.50 & 150.00 \\
\hline
\end{tabular}


Outside Ring Road

\begin{tabular}{|c|c|c|c|c|c|c|c|c|c|}
\hline & T. sparsifolium & ND & 4.00 & 5.00 & 17.50 & 120.50 & 4.75 & 22.75 & 300.00 \\
\hline & P. striatus & ND & 2.25 & 5.75 & 12.75 & 85.50 & 4.50 & 5.00 & 125.00 \\
\hline \multirow{4}{*}{$\begin{array}{l}\text { Sanothimi } \\
\text { (Brick kiln) }\end{array}$} & T. giraldii & ND & 4.25 & 6.75 & 16.00 & 97.75 & 6.50 & 82.00 & 221.75 \\
\hline & & & & & & & & & \\
\hline & T. sparsifolium & ND & 4.50 & 5.50 & 13.25 & 100.00 & 6.25 & 95.00 & 287.50 \\
\hline & P. striatus & ND & 3.75 & 6.00 & 13.25 & 86.00 & 5.25 & 32.00 & 65.75 \\
\hline \multirow[t]{3}{*}{ Bhaktapur (Itapako) } & T. giraldii & ND & 2.75 & 4.75 & 9.25 & 80.25 & 4.50 & 85.00 & 300.00 \\
\hline & T. sparsifolium & ND & 5.50 & 18.50 & 7.50 & 88.00 & 4.50 & 90.00 & 475.00 \\
\hline & P. striatus & ND & 7.00 & 4.00 & 11.00 & 81.25 & 3.25 & 26.00 & 200.00 \\
\hline \multirow[t]{3}{*}{ Chhaling VDC } & T. giraldii & ND & 7.50 & 5.00 & 11.25 & 92.25 & 4.75 & 54.00 & 53.00 \\
\hline & T. sparsifolium & ND & 7.75 & 5.25 & 12.50 & 91.75 & 6.25 & 62.50 & 80.00 \\
\hline & P. striatus & ND & 5.00 & 6.75 & 11.50 & 80.25 & 7.75 & 24.00 & 49.50 \\
\hline \multirow{3}{*}{$\begin{array}{l}\text { Nayathimi } \\
\text { (near road) }\end{array}$} & T. giraldii & ND & 5.50 & 4.25 & 13.25 & 103.50 & 4.00 & 54.00 & 44.25 \\
\hline & T. sparsifolium & ND & 6.50 & 5.50 & 13.25 & 92.50 & 5.50 & 62.50 & 75.00 \\
\hline & P. striatus & ND & 6.00 & 4.75 & 12.00 & 91.25 & 8.00 & 20.00 & 67.50 \\
\hline \multirow[t]{2}{*}{ Nayathimi (village) } & T. giraldii & ND & 7.25 & 3.50 & 11.25 & 96.50 & 3.50 & 24.00 & 41.00 \\
\hline & P. striatus & ND & 0.00 & 3.50 & 14.25 & 93.25 & 4.75 & 5.00 & 47.75 \\
\hline \multirow[t]{2}{*}{ Kirtipur (CDB) } & T. giraldii & ND & 7.25 & 4.00 & 15.00 & 100.25 & 5.00 & 12.50 & 125.00 \\
\hline & T. sparsifolium & ND & 8.25 & 3.25 & 11.75 & 91.25 & 5.25 & 16.25 & 137.00 \\
\hline \multirow[t]{2}{*}{ Transplanted sites } & Moss sp. & Cd & Co & $\mathrm{Cr}$ & $\mathbf{C u}$ & Mn & $\mathbf{N i}$ & $\mathbf{P b}$ & $\mathbf{Z n}$ \\
\hline & P. striatus & ND & 6.50 & 3.25 & 9.75 & 72.25 & 3.75 & 4.50 & 35.00 \\
\hline \multirow[t]{3}{*}{ Bungmati } & T. giraldii & ND & 9.50 & 5.50 & 17.25 & 98.00 & 2.50 & 17.50 & 97.50 \\
\hline & T. sparsifolium & ND & 8.00 & 4.25 & 33.00 & 84.25 & ND & 14.00 & 60.00 \\
\hline & P. striatus & ND & 8.75 & 6.25 & 25.50 & 50.00 & 2.00 & 4.50 & 70.75 \\
\hline \multicolumn{10}{|l|}{ Control areas } \\
\hline \multirow[t]{3}{*}{ Raniban } & T. giraldii & ND & 9.00 & 7.00 & 17.25 & 103.25 & 2.50 & 14.50 & 50.00 \\
\hline & T. sparsifolium & ND & 8.50 & 3.50 & 10.00 & 92.50 & ND & 10.00 & 33.25 \\
\hline & P. striatus & ND & 7.75 & 2.00 & 11.75 & 91.00 & ND & 5.00 & 78.25 \\
\hline \multirow[t]{3}{*}{ Shivapuri } & T. giraldii & ND & 3.00 & 4.00 & 9.00 & 102.00 & 5.50 & 8.25 & 45.00 \\
\hline & T. sparsifolium & ND & 2.00 & 2.00 & 8.50 & 109.00 & 6.00 & 5.00 & 40.50 \\
\hline & P. striatus & ND & 2.00 & 3.50 & 12.00 & 95.00 & 2.00 & 5.00 & 46.00 \\
\hline \multirow[t]{3}{*}{ Phulchowki } & T. giraldii & ND & 3.00 & 5.00 & 11.25 & 112.25 & 5.00 & 8.75 & 50.00 \\
\hline & T. sparsifolium & ND & 2.50 & 4.25 & 9.50 & 135.00 & 4.50 & 3.75 & 45.00 \\
\hline & P. striatus & ND & $\mathrm{ND}$ & 5.25 & 20.00 & 91.50 & 4.00 & 11.25 & 75.00 \\
\hline
\end{tabular}

$\mathrm{ND}=$ Not detectable 
Table 2. Mean and SD of metal concentrations in mosses and leafy liverwort transplanted for 3 months at different places inside, along, outside Ring Road and in clean areas like Raniban, Phulchowki and Shivapuri National park considered as control.

\begin{tabular}{|c|c|c|c|c|}
\hline & $\begin{array}{c}\text { Inside Ring Road } \\
\quad \text { Mean } \pm \text { SD }\end{array}$ & $\begin{array}{c}\text { Along Ring Road } \\
\text { Mean } \pm \text { SD }\end{array}$ & $\begin{array}{c}\text { Outside Ring Road } \\
\text { Mean } \pm \text { SD }\end{array}$ & $\begin{array}{c}\text { Control area } \\
\text { Mean } \pm \text { SD }\end{array}$ \\
\hline \multicolumn{5}{|c|}{ Taxiphyllum giraldii } \\
\hline Cd & $1.25 \pm 1.02$ & $2.13 \pm 0.53$ & ND & ND \\
\hline Co & $6.68 \pm 2.62 \mathrm{a}$ & $3.81 \pm 1.81 \mathrm{a}$ & $6.28 \pm 2.10 \mathrm{a}$ & $5.00 \pm 3.46 \mathrm{a}$ \\
\hline $\mathrm{Cr}$ & $12.86 \pm 9.04 \mathrm{~b}$ & $11.11 \pm 7.32 \mathrm{ab}$ & $5.00 \pm 1.12 \mathrm{a}$ & $5.33 \pm 1.53 \mathrm{a}$ \\
\hline $\mathbf{C u}$ & $22.46 \pm 8.26 \mathrm{c}$ & $21.11 \pm 8.74 b c$ & $13.78 \pm 2.99 \mathrm{ab}$ & $12.50 \pm 4.26 \mathrm{a}$ \\
\hline Mn & $82.00 \pm 25.87 a$ & $140.42 \pm 62.26 \mathrm{~b}$ & $96.28 \pm 7.33 \mathrm{ab}$ & $105.83 \pm 5.59 \mathrm{ab}$ \\
\hline $\mathbf{N i}$ & $7.32 \pm 3.04 \mathrm{~b}$ & $6.91 \pm 1.49 \mathrm{~b}$ & $4.47 \pm 1.18 \mathrm{a}$ & $4.33 \pm 1.61 \mathrm{a}$ \\
\hline $\mathbf{P b}$ & $71.19 \pm 7.66 \mathrm{c}$ & $63.56 \pm 17.32 \mathrm{bc}$ & $43.63 \pm 29.26 \mathrm{~b}$ & $10.50 \pm 3.47 \mathrm{a}$ \\
\hline $\mathbf{Z n}$ & $77.43 \pm 30.94 \mathrm{ab}$ & $127.97 \pm 68.64 \mathrm{ab}$ & $141.56 \pm 102.07 \mathrm{~b}$ & $48.33 \pm 2.89 \mathrm{a}$ \\
\hline \multicolumn{5}{|c|}{ Thuidium sparsifolium } \\
\hline Cd & $1.68 \pm 1.25$ & $2.38 \pm 0.18$ & ND & ND \\
\hline Co & $6.39 \pm 2.35 \mathrm{a}$ & $5.33 \pm 2.46 \mathrm{a}$ & $6.53 \pm 1.71 \mathrm{a}$ & $4.33 \pm 3.62 \mathrm{a}$ \\
\hline $\mathrm{Cr}$ & $13.39 \pm 11.20 \mathrm{bc}$ & $15.53 \pm 10.11 \mathrm{c}$ & $4.59 \pm 0.90 \mathrm{ab}$ & $3.25 \pm 1.15 \mathrm{a}$ \\
\hline $\mathrm{Cu}$ & $19.29 \pm 6.90 \mathrm{~b}$ & $23.06 \pm 6.18 \mathrm{~b}$ & $12.63 \pm 3.06 \mathrm{a}$ & $9.33 \pm 0.76 \mathrm{a}$ \\
\hline Mn & $101.32 \pm 18.29 \mathrm{a}$ & $170.89 \pm 94.80 \mathrm{~b}$ & $96.44 \pm 10.32 \mathrm{a}$ & $112.17 \pm 21.43 \mathrm{ab}$ \\
\hline $\mathbf{N i}$ & $6.46 \pm 4.31 \mathrm{a}$ & $7.39 \pm 1.80 \mathrm{a}$ & $5.43 \pm 0.67 \mathrm{a}$ & $5.25 \pm 1.06 \mathrm{a}$ \\
\hline $\mathbf{P b}$ & $68.65 \pm 15.70 \mathrm{~b}$ & $61.25 \pm 10.01 \mathrm{~b}$ & $47.25 \pm 34.47 \mathrm{~b}$ & $6.25 \pm 3.31 \mathrm{a}$ \\
\hline $\mathbf{Z n}$ & $105.54 \pm 67.46 \mathrm{ab}$ & $130.67 \pm 39.96 \mathrm{ab}$ & $179.97 \pm 157.56 \mathrm{~b}$ & $39.58 \pm 5.93 \mathrm{a}$ \\
\hline \multicolumn{5}{|c|}{ Ptychanthus striatus } \\
\hline Cd & $0.59 \pm 0.79$ & $0.88 \pm 0.65$ & ND & ND \\
\hline Co & $6.57 \pm 4.26 \mathrm{a}$ & $3.47 \pm 2.41 \mathrm{a}$ & $4.91 \pm 2.81 \mathrm{a}$ & $4.88 \pm 4.07 \mathrm{a}$ \\
\hline $\mathrm{Cr}$ & $7.07 \pm 3.00 \mathrm{ab}$ & $8.25 \pm 4.01 \mathrm{~b}$ & $6.84 \pm 4.88 \mathrm{ab}$ & $3.58 \pm 1.63 \mathrm{a}$ \\
\hline $\mathbf{C u}$ & $20.79 \pm 9.80 \mathrm{a}$ & $18.47 \pm 6.13 \mathrm{a}$ & $13.75 \pm 4.95 \mathrm{a}$ & $14.58 \pm 4.69 \mathrm{a}$ \\
\hline Mn & $90.57 \pm 19.86 \mathrm{a}$ & $97.31 \pm 14.89 \mathrm{a}$ & $79.97 \pm 13.78 \mathrm{a}$ & $92.50 \pm 2.18 \mathrm{a}$ \\
\hline $\mathbf{N i}$ & $5.40 \pm 3.67 \mathrm{a}$ & $5.84 \pm 1.78 \mathrm{a}$ & $4.91 \pm 2.09 \mathrm{a}$ & $5.63 \pm 5.13 \mathrm{a}$ \\
\hline $\mathbf{P b}$ & $32.65 \pm 19.73 \mathrm{c}$ & $26.86 \pm 14.53 \mathrm{bc}$ & $15.13 \pm 11.57 \mathrm{ab}$ & $7.08 \pm 3.61 \mathrm{a}$ \\
\hline $\mathbf{Z n}$ & $91.86 \pm 40.84 \mathrm{a}$ & $66.28 \pm 34.32 \mathrm{a}$ & $82.66 \pm 54.52 \mathrm{a}$ & $66.42 \pm 17.76 \mathrm{a}$ \\
\hline
\end{tabular}

Same letters after mean \pm SD along rows do not differ significantly $(\mathrm{P}=0.05)$ according to Duncan's Multiple range test followed after ANOVA.

ND $=$ Not detectable 
Table 3. Categorization of different study sites of Kathmandu valley on the basis of contamination factor.

\begin{tabular}{|c|c|c|c|c|c|c|c|}
\hline Study Sites & Co & $\mathrm{Cr}$ & $\mathrm{Cu}$ & Mn & $\mathbf{N i}$ & $\mathbf{P b}$ & Zn \\
\hline \multicolumn{8}{|l|}{ Inside Ring Road } \\
\hline Kalimati & 1.84 & 0.93 & 1.07 & 0.75 & 0.45 & $5.18^{*}$ & 0.90 \\
\hline Lagankhel & 1.35 & 2.12 & 3.08 & 1.05 & 2.10 & $8.18 * *$ & 1.90 \\
\hline Maitidevi & 1.97 & 1.15 & 1.47 & 0.87 & 0.88 & $6.78 *$ & 1.14 \\
\hline Pulchowk & 0.73 & 2.28 & 1.45 & 0.61 & 1.51 & $6.63 *$ & 1.73 \\
\hline Putalisadak & 1.63 & $3.49 *$ & 1.57 & 0.79 & 1.01 & $7.60 *$ & 1.78 \\
\hline Thamel (Campus) & 1.74 & $3.60 *$ & 1.73 & 1.08 & 0.96 & $6.40 *$ & 1.77 \\
\hline Thapathali & 0.50 & $5.60 *$ & 1.65 & 1.03 & 2.18 & $9.90 * *$ & 3.26 \\
\hline \multicolumn{8}{|l|}{ Along Ring Road } \\
\hline Balaju & 1.08 & 2.88 & 1.95 & 1.03 & 1.36 & $6.40^{*}$ & 1.52 \\
\hline Balkhu & 1.38 & 1.32 & 1.47 & 1.43 & 1.41 & 3.25 & 2.44 \\
\hline Chabahil & 0.34 & 2.96 & 1.14 & 1.63 & 1.16 & $7.38 *$ & 2.21 \\
\hline Gongabu Bus park & 0.46 & $5.51 *$ & 1.39 & 1.01 & 1.34 & $6.65^{*}$ & 2.57 \\
\hline Kalanki & 1.31 & $4.21 *$ & 2.08 & 1.01 & 1.34 & $7.09 *$ & 2.40 \\
\hline Koteshwor & 0.82 & 2.59 & 1.51 & 1.37 & 1.36 & $4.40 *$ & 1.38 \\
\hline Maharajgunj & 0.71 & 1.83 & 1.22 & 1.07 & 1.48 & $7.24 *$ & 1.26 \\
\hline Satdobato & 1.35 & 2.67 & 2.28 & 0.96 & 1.53 & $7.51 *$ & 2.64 \\
\hline Banasthali & 0.60 & 1.85 & 2.45 & 1.94 & 1.04 & $7.34 *$ & 2.53 \\
\hline \multicolumn{8}{|l|}{ Outside Ring Road } \\
\hline Bhaktapur campus & 0.89 & 1.40 & 1.30 & 0.99 & 0.96 & 2.00 & $4.37 *$ \\
\hline Bhaktapur-Itapako & 1.08 & 2.24 & 0.76 & 0.80 & 0.82 & $8.44 * *$ & $6.31 *$ \\
\hline Bungmati & 1.86 & 1.32 & 2.08 & 0.75 & 0.45 & 1.51 & 1.48 \\
\hline Chhaling VDC & 1.44 & 1.40 & 0.97 & 0.85 & 1.26 & $5.89 *$ & 1.18 \\
\hline Kirtipur (CDB) & 1.56 & 0.86 & 1.00 & 0.85 & 0.94 & 1.40 & 1.92 \\
\hline Nayathimi -near road & 1.28 & 1.19 & 1.06 & 0.93 & 1.18 & $5.73 *$ & 1.21 \\
\hline Nayathimi (village) & 1.03 & 0.97 & 1.12 & 0.92 & 0.92 & 2.02 & 0.91 \\
\hline Sanothimi & 0.89 & 1.50 & 1.17 & 0.91 & 1.21 & $8.77 * *$ & $3.72 *$ \\
\hline
\end{tabular}

$\mathrm{C} 1=(\mathrm{CF} 0-1)$ No contamination $\mathrm{C} 4=(\mathrm{CF}>3.5-8)$ Moderate contamination, $\mathrm{C} 2=(\mathrm{CF}>1-2)$ Suspected contamination $\mathrm{C} 5=(\mathrm{CF}>8-27)$ Severe contamination, $\mathrm{C} 3=(\mathrm{CF}>2-3.5)$ Slight contamination $\mathrm{C} 6=(\mathrm{CF}>27)$ Extreme contamination

Contamination Factor (CF) using transplanted mosses

On the basis of contamination factor $\mathrm{Co}$ and $\mathrm{Mn}$ contamination in air was negligible (C1-C2) but that of $\mathrm{Pb}$ was very high (C1-C5). Co and $\mathrm{Mn}$ showed no contamination or suspected contamination in all the transplanted sites, indicating their least presence in the air. Concentrations of $\mathrm{Cd}$ in most places were not detected, hence were not included to calculate contamination factor.

Slight contamination of $\mathrm{Ni}$ was observed at Lagankhel and Thapathali and of $\mathrm{Cu}$ at Lagankhel, Kalanki, Satdobato, Banasthali and Bugmati.

ECOPRINT VOL 19, 2012 
Moderate contamination of $\mathrm{Zn}$ was observed at some brick Kiln areas outside the Ring Road. Similarly, moderate $\mathrm{Cr}$ contamination was observed in the areas with high vehicular flow. Severe contamination of $\mathrm{Pb}$ was observed near high vehicular traffic areas like Lagankhel and Thapathali and the areas near brick kiln at Bhaktapur.

On the basis of Passive monitoring $\mathrm{Pb}, \mathrm{Cr}, \mathrm{Cd}$ and $\mathrm{Zn}$ indicated severe contamination in the Kathmandu valley (Shakya et al. 2004). But the present active monitoring study using some other mosses and leafy liverwort through transplant technique showed severe contamination of $\mathrm{Pb}$ only. $\mathrm{Cd}$ was not detected in transplants at most places. Both $\mathrm{Zn}$ and $\mathrm{Cr}$ concentrations reached up to slight to moderate contamination level in transplants. Severe contamination of metals in passive monitoring was mainly due to very high exposure time (3-5 years) than that in the active monitoring (3 months).

\section{CONCLUSION}

In the study of active monitoring using transplanted mosses, the concentrations of air borne metals (except $\mathrm{Mn}$ ) were mostly high in all transplanted sites than that in the control sites. It shows that the transplantation of the mosses has been found to be quite useful for monitoring the intensity and trend of air pollution. Transplants of the mosses placed in different sites indicated air contamination, mainly by $\mathrm{Pb}$ and $\mathrm{Cr}$ and to lesser extent by $\mathrm{Zn}$, as the important pollution source in the study sites is mainly vehicular emission.

On the basis of active monitoring study, the Kathmandu valley can be classified as possessing an extreme contamination distribution of $\mathrm{Pb}, \mathrm{Cr}$ and $\mathrm{Zn}$, but on the whole having moderate level of contamination of other metals. On the basis of contamination factors, contamination of $\mathrm{Co}, \mathrm{Cu}$, $\mathrm{Mn}$ and $\mathrm{Ni}$ in air of Kathmandu valley is relatively low. Contamination of airborne heavy metals $(\mathrm{Pb}$ and $\mathrm{Cr}$ ) is mostly high inside and along Ring Road.

\section{ACKNOWLEDGEMENTS}

The scholarship provided to Dr. K. Shakya by the Nepal Academy for Science and Technology (NAST), Khumaltar, Lalitpur is greatly acknowledged. We wish to thank the Department of Botany, Amrit Campus, Tribhuvan University, Kathmandu and Nepal Bureau of Standards and Metrology, Balaju, Kathmandu for providing laboratory facilities. We are indebted to Dr. Virendra Nath and Dr. D. C. Zhang for moss identification.

\section{REFERENCES}

Chettri, M.K, K.B. Thapa, K. Paudel and B. Acharya. 2001. Biomonitoring of toxic heavy metals in Kathmandu valley using lichens. Ecoprint 8:69-75.

Christersen, E.R. and V.P. Guinn. 1979. Zinc from automobile tyres in urban runoff. ASCE $J$. Environ. Eng. 105:165-168.

Clarke, L.B. and L.L. Sloss. 1992. Trace ElementEmissions from Coal Combustion and Gasfication. IEA report, IEACR/49. IEA. Coal Research, London.

Councell, T.B., K.U. Duckenfield, E.R. Landa and E. Callender. 2004. Tire-wear particles as a source of zinc to the environment. Environmental Science and Technology 38:4206-4214.

DoTM. 2010. Vehicle Registration Stastistics. Department of Transport Managment, Government of Nepal, Kathmandu.

ENPHO. 2001. Status of Brick Kilns in the Kathmandu Valley. Environment and Public Health Organization, Kathmandu.

Fernandez, J.A. and A. Carballeira. 2001. Evaluation of contamination, by different elements, in terrestrial mosses. Archives of Environ. Contamin. Toxicol. 40:461-468.

Fernandez, J.A., A. Ederra and A. Carballeira. 1997. Biocontrol of the atmospheric 
deposition of heavy metals in Navarra (Spain) by terrestrial mosses. Munibe 49:101-109.

Fernandez, J.A., A. Rey and A. Carballeira. 2000. An extended study of heavy metal deposition in Galicia (NW Spain) based on moss analysis. Sci. Total Environ. 254:31-44.

Figueira, R. and T. Ribeiro. 2005. Transplants of aquatic mosses as Biomonitors of metals released by a mine effluent. Environ. Pollu. 136:293-301.

Fytianos, K., V. Samanidou and T. Agelidis. 1985. Comparative study of heavy metals pollution in various rivers and lakes of Northern Greece. Ambio. 15:42-44.

Gailey, F.A.Y. and O.L. Lloyd. 1986. Methodological investigations into low technology monitoring of atmospheric metal pollution: Parts 1, 2, 3. Environ. Pollu. (Series B) 12:41-59.

Goodman, G.T. and T.M. Roberts. 1971. Plants and soil as indicators of metals in the air. Nature 231:287-292.

Loppi, S. and I. Bonini. 2000. Lichens and mosses as biomonitors of trace elements in areas with thermal springs and fumarole activity (Mt. Amiata, Central Italy). Chemosphere 41:13331336.

Makholm, M.M. and D.J. Miadenoff. 2005. Efficacy of a biomonitoring (moss bag) technique for determining element deposition trends on a mid-range (375) scale. Environ. Mon. Assess. 104:1-18.

Palmieri, F., R. Neri, C. Benco and L. Serracca. 1997. Lichens and mosses as bioindicators and bioaccumulators in air pollution monitoring. $J$. Environ. Patho. Toxico. Oncol. 16(2 and 3):175-190.

Ruhling, A. and G. Tyler. 1968. An ecological approach to the lead problem. Bot. Not. 122:248-342.
Sawidis, T., G. Zachariadis, J. Stratis and E. Ladoukakis. 1993. Mosses as biological indicators for monitoring of heavy metal pollution. Fresenius Environmental Bull. 2:193-199.

Saxena, D.K. and S. Arfeen. 2010. Metal deposition pattern in Kumaon hills (India) through active monitoring using moss Racomitrium crispulum Iran J. Environ Health Sci. Eng. 7:103-114.

Saxena, D.K., K. Srivastava and S. Singh, S. 2008. Biomonitoring of metal deposition by using moss transplant method through Hypnum cupressiforme (Hedw.) in Mussoorie. Journal of Environmental Biology 29(5):683-688.

Schaug, J., J.P. Rambaek, E. Steinnes and R.C. Henry. 1990. Multivariate analysis of trace element data from moss samples used to monitor atmospheric deposition. Atmos. Environ 24A(10):2625-2631.

Shakya, K., M.K. Chettri and T. Sawidis. 2004. Appraisal of some mosses for biomonitoring air borne heavy metals in Kathmandu valley. Ecoprint 2(1):35-49.

Shrestha, B. 2000. Air pollution status of Kathmandu, Nepal. Air pollution in mega cities of Asia. Seol, Korea.

Steinnes, E. 1989. Biomonitors of air pollution by heavy metals. In: Control and Fate of Atmospheric Trace Metals. (eds.) Pacyna, J.M. and B. Ottar. NATO ASI Series 268 Kluwer Academic Publishers, Dordrecht. pp. 321-335.

Steinnes, E. 1995. A critical evaluation of the use of naturally growing moss to monmitor the deposition of atmospheric metals. Sci. Tot. Environ. 160:243-249.

Stennies, E., J.P. Rambaek and J.E. Hanssen. 1992. Large scale multi-element survey of atmospheric deposition using naturally growing moss as biomonitors. Chemosphere 25:735-752. 
Sucharova, J. and I. Suchara. 2000. Potential and limits of moss and humus indicators to monitor atmospheric deposition levels of elements in the Czech Republic. Research Institute of Ornamental Gardening 252:153-156.

Tuba, Z. and Zs. Csintalan. 1993. Bioindication of road motor traffic caused heavy metal pollution by lichen transplants. In: Plants as Biomonitors - Indicators for Heavy Metal Pollution of the Terrestrial Environment. (ed.) B. VHC-Publisher Inc., Weinheim-New York, pp. 206-215.

Tyler, G. 1970. Moss Analysis- A method for surveying heavy metal deposition, In: Proc. Sec. Int. Clean Air Congress. (eds.) England, H.M. and W.T. Berry. Academic Press, New York.

Vazquez, M.D., J. Lopez and A. Carballeira. 1999. Uptake of heavy metals to the extracellular and intracellular compartments in three species of aquatic bryophyte. Ecotoxico. Environ. Safety. 44:12-24.
Viskeri, E.L., R. Rekila, S. Roy, O. Lehto, J. Ruuskanen and L. Karenlampi. 1997. Airborne pollutants along a roadside assessment using snow analysis and moss bags. Environ. Pollut. 97:153-160.

Ward, N.J. 1989. Multielement contamination of British motorway environments. In: Heavy Metals in the Environment. International Conference, Vol. II. (ed.) Vernet, J.P. CEP Consultants, Edinburgh, pp. 279-282.

Ward, N.T. 1988. Environmental contamination of aluminium and other elements in North Comwall as the water treatment works incident. In: Heavy Metals in the Environment, Vol. 1. (ed.) Vernet, J.P. Geneva.

Welz, B. 1985. Atomic Absorption Spectrometry. $\mathrm{VCH}$, Weinheim, Germany.

Wilson, B.L., R.R. Schwarzer and N. Etonyeaku. 1986. The evaluation of heavy metals (chromium, nickel and cobalt) in the aqueos sediment surrounding a coal burning generating plant J. Environ. Sci. Health 21:791-808. 